\title{
Akuntabilitas dan Transparansi Pengelolaan Anggaran Pendapatan dan Belanja Desa (APBDes) Tahun 2016
}

\author{
Rizal \\ rizal@iainbatusangkar.ac.id \\ Sri Adella Fitri \\ Sri.af@iainbatusangkar.ac.id \\ Devi Rantika
}

\begin{abstract}
Accountability and transparency in managing the 2016 nagari income and expenditure budget (APB Nagari) at the Balimbing nagari guardian office is of particular concern since the Nagari Government obtained direct funding from the central government. The Balimbing nagari government has not published the accountability report for the implementation of budget realization to the public in writing. Based on domestic ministerial regulation number 113 of 2014 concerning village financial management in chapter $V$ of article 40 paragraph 1 and 2 that the accountability report for budget realization must be published through media information that is easily accessible to the public. Media information includes bulletin boards, community radio, and other information media. The purpose of this study was to determine the accountability and transparency of the management of the 2016 nagari income and expenditure budget (APB Nagari) in Balimbing nagari. The type of research used in this study is field reserch or field research. The method used is descriptive with a qualitative approach. Data collection authors do through interviews and documentation. The results showed that the Balimbing nagari government in Rambat sub-district Tanah Datar district had applied the principle of accountability and transparency in the management of the APB Nagari. In general, accountability and transparency have begun to be implemented well. However, there are still several indicators of accountable and transparent criteria that have not been fulfilled by the Balimbing nagari government.
\end{abstract}

\section{Keywords: Accountability, Transparency, Management of Regional Budget}

\section{Abstrak}

Akuntabilitas dan transparansi pengelolaan anggaran pendapatan dan belanja nagari (APB Nagari) tahun 2016 pada kantor wali nagari Balimbing menjadi perhatian khusus sejak Pemerintah Nagari memperoleh kucuran dana langsung dari pemerintah pusat. Pemerintah nagari Balimbing belum mempublikasikan laporan pertanggungjawaban pelaksanaan realisasi anggaran kepada masyarakat secara tertulis. Berdasarkan peraturan menteri dalam negeri nomor 113 tahun 2014 tentang pengelolaan keuangan desa pada bab V pasal 40 ayat 1 dan 2 bahwa laporan pertanggungjawaban realisasi anggaran harus dipublikasikan melalui media informasi yang mudah diakses oleh masyarakat. Media informasi tersebut antara lain papan pengumuman, radio komunitas, dan media informasi 
lainnya. Tujuan dari penelitian ini adalah untuk mengetahui akuntabilitas dan transparansi pengelolaan anggaran pendapatan dan belanja nagari (APB Nagari) tahun 2016 pada nagari Balimbing.

Jenis penelitian yang digunakan dalam penelitian ini adalah field reserch atau penelitian lapangan. Metode yang digunakan deskriptif dengan pendekatan kualitatif. Pengumpulan data penulis melakukan melalui wawancara dan dokumentasi. Hasil penelitian menunjukkan bahwa pemerintah nagari Balimbing kecamatan Rambatan Kabupaten Tanah Datar sudah menerapkan prinsip akuntabilitas dan transparansi dalam pengelolaan APB Nagari. Secara umum akuntabilitas dan transparansi sudah mulai diterapkan dengan baik. Namun, masih ada beberapa indikator dari kriteria akuntabel dan transparan yang belum terpenuhi oleh pemerintah nagari Balimbing.

\section{Kata Kunci: Akuntabilitas, Transparansi, Pengelolaan APBDes}

\section{PENDAHULUAN}

Akuntabilitas akan semakin membaik jika didukung oleh suatu system akuntansi yang menghasilkan informasi yang akurat, handal, tepat waktu, serta dapat dipertanggungjawabkan (Lestari, 2014). Untuk terwujudnya transparansi dan akuntabilitas harus didukung dengan adanya sistem pengelolaan dan pelaporan keuangan yang baik agar dapat menghasilkan informasi yang relevan dan mudah dimengerti.

Dengan disahkannya UU Nomor 6 Tahun 2014 tentang Desa, desa diberikan kesempatan yang besar untuk mengurus tata pemerintahannya sendiri serta pelaksanaan pembangunan untuk meningkatkan kesejahteraan dan kualitas hidup masyarakat desa. Selain itu pemerintah desa diharapkan untuk lebih mandiri dalam mengelola pemerintahan dan berbagai sumber daya alam yang dimiliki, termasuk didalamnya pengelolaan keuangan dan kekayaan milik desa. Begitu besar peran yang diterima oleh desa, tentunya disertai dengan tanggungjawab yang besar pula. Oleh karena itu, pemerintah desa harus bisa menerapkan prinsip akuntabilitas dalam tata pemerintahannya, dimana semua akhir kegiatan penyelenggaraan pemerintahan desa harus dapat dipertanggungjawabkan kepada masyarakat desa sesuai dengan ketentuan (BPKP, 2015, p. 1).

APBN-P 2016 telah mengalokasikan Dana Desa sebesar $\pm \mathrm{Rp}$ 46, 982 triliun kepada seluruh desa yang tersebar di Indonesia. Jumlah desa yang ada pada 
tahun 2016 sebanyak 74.754 desa (Kemenkeu, 2016). Selain Dana Desa, sesuai Peraturan Bupati Tanah Datar Nomor 11 tahun 2016, desa memiliki pendapatan asli desa, pendapatan transfer berupa alokasi dana desa, dana desa, bagian dari hasil pajak dan retribusi kabupaten/kota, dan bantuan keuangan dari APBD provinsi/ kabupaten/kota.

Desa atau yang selanjutnya disebut nagari. Nagari Balimbing Kecamatan Rambatan Kabupaten Tanah Datar merupakan salah satu nagari yang pada tahun 2016 memperoleh anggaran pendapatan dari pemerintah pusat. Adapun laporan realisasi anggaran pendapatan dan belanja nagari (APB Nagari) Balimbing pada tahun 2016, dapat dilihat pada tabel dibawah ini:

\section{Tabel 1}

\section{Laporan Realisasi Pelaksanaan}

Anggaran Pendapatan Belanja Desa Pemerintah Nagari Balimbing Tahun anggaran 2016

\begin{tabular}{|c|c|c|c|c|}
\hline $\begin{array}{l}\mathbf{N} \\
\mathbf{0}\end{array}$ & Uraian & $\begin{array}{l}\text { Anggaran } \\
\text { (Rp) }\end{array}$ & $\begin{array}{l}\text { Realisasi } \\
\quad(\mathbf{R p})\end{array}$ & $\begin{array}{l}\text { Lebih/ } \\
\text { Kurang } \\
\text { (Rp) }\end{array}$ \\
\hline \multirow[t]{10}{*}{1} & PENDAPATAN & $\mathbf{0}$ & $\mathbf{0}$ & $\mathbf{0}$ \\
\hline & Pendapatan Asli Nagari & 0 & 0 & 0 \\
\hline & Lain-lain Pendapatan Asli Nagari & & & \\
\hline & Yang sah & 2.187.916.700 & 2.256.363.550 & 68.446 .850 \\
\hline & Dana Transfer & 688.773 .000 & 688.773 .000 & 0 \\
\hline & Dana Nagari & 44.406 .700 & 42.853 .550 & $(1.553 .150)$ \\
\hline & \multicolumn{4}{|l|}{ Bagian dari Hasil Pajak Daerah dan } \\
\hline & Retribusi Daerah & 1.162 .737 .000 & 1.162 .737 .000 & 0 \\
\hline & Alokasi Dana Nagari (ADN) & 12.000 .000 & $\begin{array}{r}12.000 .000 \\
350.000 .000\end{array}$ & 0 \\
\hline & $\begin{array}{l}\text { Bantuan Keuangan dari APBD } \\
\text { Provinsi } \\
\text { Bantuan Keuangan Dari APBD } \\
\text { Kabupaten }\end{array}$ & 280.000 .000 & 350.000 .000 & 70.000 .000 \\
\hline \multicolumn{2}{|r|}{ Jumlah Pendapatan } & 2.187.916.700 & 2.256.363.550 & 68.446 .850 \\
\hline \multirow[t]{7}{*}{2} & BELANJA & & & \\
\hline & Belanja Nagari & 2.316.535.393 & 1.879.714.666 & 436.820 .72 \\
\hline & Belanja Pegawai & 280.735 .300 & 253.795 .000 & 7 \\
\hline & Belanja Barang dan Jasa & 711.522 .583 & 444.041 .642 & 26.940 .300 \\
\hline & \multirow[t]{3}{*}{ Belanja Modal } & 1.324.277.510 & 1.181 .878 .024 & 267.480 .94 \\
\hline & & & & $\begin{array}{r}1 \\
142.399 .48\end{array}$ \\
\hline & & & & 6 \\
\hline \multirow{2}{*}{\multicolumn{2}{|c|}{ Jumlah Belanja }} & 2.316.535.393 & 1.879.714.666 & 436.820.72 \\
\hline & & & & 7 \\
\hline \multicolumn{2}{|r|}{ Lebih/ kurang } & (128.618.693) & 376.648.884 & $\mathbf{5 0 5 . 2 6 7 . 5 7}$ \\
\hline
\end{tabular}




\begin{tabular}{|c|l|r|r|r|}
\hline 3 & PEMBIAYAAN & & \\
& $\begin{array}{l}\text { Penerimaan Pembiayaan } \\
\text { Sisa Lebih Perhitungan Anggaran } \\
\text { (SiLPA) }\end{array}$ & 128.618 .693 & 128.618 .693 & 0 \\
\hline & Jumlah Pembiayaan & $\mathbf{1 2 8 . 6 1 8 . 6 9 3}$ & $\mathbf{1 2 8 . 6 1 8 . 6 9 3}$ & $\mathbf{1 2 8 . 6 1 8 . 6 9 3}$ \\
\hline & Sisa Lebih Perhitungan Anggaran & $\mathbf{0}$ & $\mathbf{5 0 5 . 2 6 7 . 5 7 7}$ & $\mathbf{5 0 5 . 2 6 7 . 5 7}$ \\
& & & $\mathbf{7}$ \\
\hline
\end{tabular}

Sumber: Laporan Realisasi Pelaksanaan Anggaran Tahun 2016 Pemerintahan Nagari Balimbing.

Tabel 1 menunjukan laporan realisasi anggaran pendapatan dan belanja nagari Balimbing tahun anggaran 2016. Anggaran pendapatan pada tahun 2016 berjumlah $\mathrm{Rp} 2.187 .916 .700,-$ dan realisasinya berjumlah $\mathrm{Rp} 2.256 .363 .550,-$. Bantuan keuangan dari APBD kabupaten dana yang diterima oleh pemerintahan nagari ternyata melebihi dari dana yang dianggarkan sebesar $\mathrm{Rp} 70.000 .000$,- dan bagian dari hasil pajak daerah dan retribusi daerah dana yang diterima ternyata kurang dari dana yang dianggarkan sebesar Rp 1.553.150,-, sehingga memperoleh kelebihan pendapatan sebesar Rp 68.446.850,- dari yang dianggarkan. Anggaran belanja pada tahun 2016 berjumlah Rp 2.316.535.393,- sedangkan realisasinya berjumlah $\mathrm{Rp}$ 1.879.714.666,- sehingga memperoleh selisih sebesar Rp 436.820.727,-. Selisih ini disebabkan oleh: Belanja pegawai yang dianggarkan sebesar 280.735.300,- terealisasi sebesar Rp 253.795.000,- selisih Rp 26.940.300, belanja barang dan jasa yang dianggarkan sebesar Rp 711.522.583,- terealisasi sebesar Rp 444.041.642,- selisih Rp 267.480.941, dan belanja modal yang dianggarkan sebesar Rp 1.324.277.510,- terealisasi sebesar Rp 1.181.878.024,selisih Rp 142.399.486,-. Jadi, total kelebihan atau surplus yang diperoleh pada tahun 2016 sebesar Rp 505.267.577,- didapat dari kelebihan penerimaan pendapatan sebesar Rp 68.446.850,- ditambah dengan belanja yang dianggarkan dengan yang terealisasi sebesar Rp 436.820.727,--. Jadi, semakin tinggi keterbukaan dan tanggungjawab pemerintah nagari dalam pengelolaan Alokasi Dana Nagari (ADN) dan APB Nagari, maka sangat diperlukan akuntabilitas dan transparansi dari pemerintah nagari dalam pengelolaan APB Nagari sehingga diperlukan peran dari perangkat nagari untuk membantu wali nagari dalam mengelola APBNagari.

Berdasarkan Permendagri Nomor 113 Tahun 2014 tentang Pedoman Pengelolaan Keuangan Desa pasal 2 ayat (1) mengharuskan agar pengelolaan 
keuangan desa dilakukan berdasarkan asas-asas transparan, akuntabel dan partisipatif serta tertib dan disiplin anggaran. Pengelolaan keuangan desa dikelola dalam masa 1 tahun anggaran, yakni mulai tanggal 1 Januari sampai dengan tanggal 31 Desember. Disamping itu, Permendagri No 113 Tahun 2014 ini diharapkan dapat menjadi pedoman dalam pengelolaan keuangan desa karena didalamnya telah mencakup berbagai prosedur pengelolaan keuangan desa mulai dari perencanaan, pelaksanaan, penatausahaan, pelaporan sampai dengan pertanggungjawaban.

Berdasarkan wawancara awal penulis dengan Bapak Yasripen, S.Ag selaku sekretaris Nagari Balimbing pada hari Rabu tanggal 15 Maret 2017, permasalahan yang terjadi terkait pengelolaan APB Nagari yaitu laporan realisasi APB Nagari tersebut belum dipublikasikan secara tertulis kepada masyarakat Nagari Balimbing. Sedangkan salah satu bentuk pelaksanaan akuntabilitas oleh pemerintah adalah dengan mempublikasi APB Nagari kepada masyarakat melalui media informasi yang mudah diakses oleh masyarakat sebagaimana tercantum dalam permendagri nomor 113 tahun 2014 Bab V pasal 40 ayat 1 dan 2 (Yasripen, Wawancara, 15 Maret 2017).

Beberapa fenomena di atas memunculkan beberapa pertanyaan yang menarik untuk ditemukan jawabannya. Bagaimana akuntabilitas dan transparansi dalam pengelolaan APB Nagari? Apa sajakah kendala yang dihadapi pemerintah nagari Balimbing dalam pengelolaan APB Nagari?

\section{PENELITIAN TERDAHULU}

Hanifah (2015) menyimpulkan bahwa manajemen keuangan Desa Kepatihan sudah berdasarkan Peraturan Menteri Dalam Negeri Nomor 37 tahun 2007 yang menunjukkan pelaksanaan yang akuntabel dan transparan yang dilihat dari pelaporan pertangungjawaban Anggaran Pendapatan Belanja Desa (APBDesa), namun dari sisi pencatatan akuntansi masih diperlukan adanya pembinaan dan pelatihan lebih lanjut, karena belum sepenuhnya sesuai dengan ketentuan. Hambatan utamanya adalah belum efektifnya pelatihan para perangkat desa dan kompetensi sumber daya manusia, sehingga masih memerlukan perhatian khusus dari aparat pemerintah desa secara berkelanjutan. Hal yang sama 
diungkapkan Faridah (2015), bahwa Desa Sidogedungbatu Kecamatan Sangkapura Kabupaten Gresik telah melaksanakan prinsip-prinsip transparansi dan akuntabilitas pada pengelolaan APBDes tahun anggaran 2015. Secara umum transparansi dan akuntabilitas di Desa Sidogedungbatu Kecamatan Sangkapura Kabupaten Gresik sudah berjalan dengan baik, walaupun masih ada beberapa kelemahan yang masih harus diperbaiki.

Kumalasari (2016) dalam penelitiannya menunjukkan bahwa pemerintah Desa Bomo Kecamatan Rogojampi Kabupaten Banyuwangi telah melaksanakan prinsip-prinsip transparansi dan akuntabilitas pada pengelolaan ADD. Perencanaan dan pelaksanaan Alokasi Dana Desa telah menerapkan prinsip transparansi dan akuntabilitas. Sedangkan Pertanggungjawaban ADD secara fisik sudah menunjukkan pelaksanaan yang transparan dan akuntabel, namun dari sisi administrasi masih diperlukan adanya perbaikan sehingga perlu pembinaan lebih lanjut, karena belum sepenuhnya sesuai dengan ketentuan peraturan perundang undangan. Hal yang berbeda diungkapkan oleh Amirruddin dkk (2012) bahwa masyarakat Kabupaten Luwu Timur belum merasakan transparansi pengelolaan APBDes karena masyarakat kurang dilibatkan, hal ini juga didorong tidak terbukanya pemerintah desa sehingga masyarakat kurang mengetahui mengenai anggaran yang terpakai.

\section{METODE PENELITIAN}

Metode yang digunakan adalah kualitatif. Penelitian kualitatif adalah penelitian untuk memahami fenomena yang sedang terjadi secara alamiah (natural) dalam keadaan-keadaan yang sedang terjadi secara alamiah (Ahmadi, 2014, p. 15). Metode Deskriptif adalah penelitian yang berusaha mendiskripsikan suatu gejala, peristiwa, kejadian yang terjadi saat sekararang (Noor, 2011, p. 34). Teknik pengumpulan data dilakukan menggunakan teknik wawancara dengan pihak-pihak yang terkait.

\section{HASIL DAN PEMBAHASAN}

\section{Akuntabilitas pengelolaan APB Nagari}


Dalam pengelolaan APB Nagari, pemerintah nagari harus memenuhi asas akuntabel. Akuntabel artinya penyelenggaraan pemerintahan harus dipertanggungjawabkan kepada publik. Pemerintah nagari harus bisa mempertanggungjawabkan dana yang telah diterimanya dan dana yang telah dikeluarkan untuk pembiayaan dan pembangunan.

Pemerintah nagari dikatakan akuntabel dalam pengelolaan anggaran pendapatan belanja desa apabila memenuhi kriteria beserta indikator sebagai berikut:

a. Mampu menyajikan informasi penyelenggaraan pemerintah secara terbuka, cepat, dan tepat.

1) Pemerintah nagari menyajikan informasi penyelenggaraan pemerintah berdasarkan peraturan perundang-undangan yang berlaku dan menyampaikan laporan realisasi pelaksanaan kepada bupati.

2) Pemerintah nagari Balimbing menyampaikan laporan pertanggungjawaban pelaksanaan realisasi anggaran tiap semester kepada Bupati Tanah Datar..

Pemerintah nagari Balimbing membuat laporan pertanggungjawaban (LPj) nagari ada 3 (tiga) laporan yaitu:

a) LKPj (Laporan Keterangan Pertanggungjawaban) yaitu laporan pertanggungjawaban yang dilaporkan oleh pemerintah nagari kepada badan permusyawaratan rakyat nagari (BPRN).

b) LPPN (Laporan Penyelenggaraan Pemerintah Nagari) yaitu laporan pertanggungjawaban yang dilaporkan kepada bupati.

c) ILPPN (Informasi Laporan Penyelenggaraan Pemerintah Nagari) yaitu laporan pertanggungjawaban yang dilaporkan kepada masyarakat. Bentuk ILPPN yaitu berupa informasi mengenai daftar kegiatan pembangunan fisik nagari Balimbing dan daftar kegiatan pemberdayaan nagari Balimbing tahun anggaran 2016 yang ada di spanduk atau baliho yang ada di kantor wali nagari Balimbing. 
Bendahara nagari membuat laporan pertanggungjawaban yang dilaporkan kepada wali nagari setiap bulan. Setiap 3 (tiga) bulan, laporan tersebut dilakukan penutupan atas persetujuan wali nagari. Setelah masa anggaran berakhir, bendahara nagari membuat laporan pertanggungjawaban dan dilaporkan kepada wali nagari. Kemudian, laporan tersebut dilaporkan oleh wali nagari kepada BPRN melalui rapat. Cara pelaporan kepada bupati Tanah Datar yaitu laporan tersebut berdasarkan aplikasi siskeudes, laporan tersebut dilaporkan melalui dinas PMD PPKB bagian pemdes. Laporan yang akan dilaporkan ke bupati tersebut sesuai dengan apa yang diminta. Laporan-laporan yang diminta bupati berupa LPPN (Laporan Penyelenggaraan pemerintah nagari) dan dilampirkan LKPj (Laporan Keterangan Pertanggungjawaban) (Jeli Fitrina, Wawancara, 18 Juli 2017).

3) Pemerintah nagari menyampaikan laporan pertanggungjawaban pelaksanaan realisasi anggaran kepada bupati paling lambat 1 (satu) bulan setelah masa anggaran berakhir.

Peraturan nagari tentang laporan pertanggungjawaban pelaksanaan APB Nagari dan keputusan wali nagari tentang keterangan pertanggungjawaban wali nagari disampaikan kepada Bupati. Waktu penyampaian paling lambat 7 (tujuh) hari kerja setelah peraturan nagari ditetapkan.

Wali Nagari menurut Permendagri Nomor 113 tahun 2014 menyampaikan kepada Bupati setiap akhir tahun anggaran laporan yang meliputi :

a) Laporan Pertanggungjawaban Realisasi Pelaksanaan APBDesa Tahun Anggaran.

b) Laporan Kekayaan Milik Desa per 31 Desember Tahun Anggaran berkenaan

c) Laporan Program Pemerintah dan Pemerintah Daerah yang masuk ke desa. 
Pemerintah nagari telah menyampaikan laporan pertanggung-jawaban kepada Bupati Tanah Datar paling lambat 1 (satu) bulan setelah masa anggaran berakhir. LPPN dibuat bersamaan dengan LKPj dan ILPPN. Dan dilaporkan beriringan dengan LKPj dan ILPPN. Pemerintah nagari juga menyampaikan laporan pertanggungjawaban kepada Masyarakat Nagari. Wali Nagari yang menyampaikan kepada BPRN dan masyarakat nagari melalui rapat. Akan tetapi, belum diinformasikan kepada masyarakat nagari secara tertulis dan dengan media informasi yang mudah diakses oleh masyarakat (Yasripen, Wawancara, 4 Juli 2017).

b. Mampu memberikan pelayanan yang memuaskan bagi publik

1) Ketepatan waktu dalam pelayanan Pemerintah nagari Balimbing telah tepat waktu dalam memberikan pelayanan kepada masyarakat nagari.

2) Kesopanan dan keramahan dalam memberikan pelayanan Pemerintah nagari telah memberikan pelayanan dengan sopan dan ramah kepada masyarakat.

3) Kenyamanan lingkungan

Pemerintah nagari telah memberikan kenyamanan lingkungan kepada masyarakat dalam memberikan pelayanannya. Contohnya dengan menyediakan tempat duduk di lobi kantor wali, agar masyarakat bisa menunggu jadwal pelayanan dengan nyaman.

4) Kepastian jadwal pelayanan Pemerintah nagari telah memberikan kepastian jadwal pelayanan kepada masyarakat nagari.

5) Keadilan mendapatkan pelayanan Pemerintah nagari telah memberikan pelayanan yang adil kepada masyarakat tanpa memandang siapa yang yang akan dilayaninya dan tanpa membeda-bedakan masyarakat yang akan dilayaninya. 
Berdasarkan hasil wawancara dengan Ibu Jeli Fitrina, S.Pt, pemerintah nagari Balimbing sudah memberikan pelayanan sebaikbaiknya tanpa memandang siapa yang akan dilayani dan tanpa membeda-bedakannya dan telah memberikan pelayanan yang ramah, sopan, serta tepat waktu.

c. Mampu memberikan ruang bagi masyarakat untuk terlibat dalam proses pembangunan pemerintah

1) Masyarakat terlibat dalam rapat paripurna atau rapat dengar pendapat dan masyarakat menyampaikan pendapat dan ide-idenya mengenai rencana kegiatan pembangunan nagari.

Untuk menciptakan anggaran yang partisipatif, masyarakat harus ikut serta dalam pembahasan dan penetapan anggaran desa. Masyarakat memberikan usulan mengenai kegiatan pembangunan yang akan dilakukan di nagari tersebut.

Dari penetapan peraturan nagari tentang APB Nagari masyarakat ikut terlibat, akan tetapi tidak seluruh masyarakat yang terlibat. Hanya lembaga-lembaga masyarakat yang terlibat. Karena, yang ditetapkan tersebut merupakan usulan dari keseluruhan masyarakat pada saat pra musyawarah yang diadakan di masing-masing jorong (Yasripen, Wawancara, 4 Juli 2017).

2) Masyarakat ikut serta menjadi panitia pelaksanaan pembangunan nagari.

Sebelum pelaksanaan kegiatan pembangunan fisik, dilakukan musyawarah dan disosialisasikan kepada masyarakat tentang kegiatan yang akan dilaksanakan, berapa dananya, dari mana sumber dananya, dan bobot kegiatan yang akan dilaksanakan. Contohnya rebat beton jalan, dari rebat beton jalan berapa panjang, lebar, ketebalan, berapa semen, pasir dan kerikil yang dibutuhkan. Dalam musyawarah tersebut yaitu menetapkan siapa yang akan menjadi TPK (Tim pelaksana kegiatan), masyarakat yang 
disepakati dalam musyawarah akan ditetapkan menjadi anggota TPK (Yasripen, Wawancara, 4 Juli 2017).

d. Mampu menjelaskan dan mempertanggungjawabkan setiap kebijakan publik secara proporsional

1) Pemerintah nagari Balimbing menyampaikan laporan pertanggung-jawaban pelaksanaan realisasi anggaran kepada masyarakat desa melalui rapat/ musyawarah nagari.

Pemerintah nagari Balimbing telah menyampaikan laporan realisasi pelaksanaan APB Nagari kepada mayarakat nagari melalui rapat, karena sudah menjadi tanggungjawab dari pemerintah nagari untuk menyampaikan laporan pertanggungjawaban kepada Masyarakat Nagari. Wali Nagari yang menyampaikan kepada BPRN dan masyarakat nagari melalui rapat (Yasripen, Wawancara, 4 Juli 2017).

2) Pemerintah nagari Balimbing mempertangungjawabkan setiap kebijakan-kebijakan anggaran yang diambil dan menjelaskan kepada masyarakat mengenai dampak kebijakan anggaran tersebut dimasa yang akan datang.

Dalam penyusunan APB Nagari berawal dari masyarakat, kegiatan-kegiatan yang akan didanai dengan APB Nagari terlebih dahulu diadakan pra musyawarah di tingkat jorong untuk membicarakan atau menggali kebutuhan-kebutuhan yang ada jorong dengan menghadirkan seluruh komponen yang ada di jorong. Hasil kesepakatan pra musyawarah yang diadakan ditingkat jorong yaitu berupa kegiatan-kegiatan yang akan didanai oleh APB Nagari dengan dilampirkan daftar hadir dan berita acara. Setelah semua jorong yang ada di Nagari mengadakan musyawarah, maka hasil musyawarah tersebut direkap seluruh kegiatan-kegiatan yang diusulkan oleh masyarakat jorong pada saat mengadakan musyawah pembangunan ditingkat nagari. Setelah diputuskan di nagari kegiatan-kegiatan tersebut pada tahun 
yang bersangkutan, langkah selanjutnya yaitu penyusunan APB Nagari dengan catatan seluruh usulan masyarakat jorong harus tercantum dalam rencana kegiatan pembagunan nagari (RKP Nagari). Langkah selanjutnya, pemerintah nagari menyusun rancangan APB Nagari, setelah rancangan APB Nagari disusun, selanjutnya akan diajukan kepada BPRN untuk dipelajarinya. Setelah itu, diadakan musyawarah antara BPRN dan pemerintah nagari mengenai penetapan rancangan peraturan nagari mengenai APB Nagari. Setelah rancangan peraturan nagari tentang APB Nagari tersebut disepakati, langkah selanjutnya yaitu mengajukan kepada kecamatan untuk dievaluasi jika ada hal-hal yang telah dianggarkan tersebut menyalahi aturan, jika ada, maka akan diberikan solusi oleh pemerintah kecamatan, apakah kegiatan tersebut boleh dianggarkan atau dikeluarkan dari anggaran. Setelah selasai dievaluasi oleh pemerintah kecamatan, selanjutnya pemerintah nagari akan memperbaiki rancangan APB Nagari berdasarkan hasil evaluasi, kemudian diajukan kepada BPRN untuk ditetapkan sebagai peraturan nagari tentang APB Nagari (Yasripen, Wawancara, 4 Juli 2017).

e. Ada sarana bagi publik untuk menilai kinerja pemerintah nagari

Penilaian kinerja pemerintah nagari dilaksanakan dengan tujuan agar pemerintah nagari bisa mendengarkan setiap ide-ide dan keluh kesah dari masyarakat. Dengan adanya penilaian kinerja tersebut, diharapkan pemerintahan nagari Balimbing semakin baik untuk kedepannya.

Berdasarkan hasil wawancara dengan Ibu Jeli Fitrina selaku bendahara nagari, belum ada sarana untuk penilaian kinerja pemerintahan nagari yang disediakan oleh pemerintah nagari, baik berupa kotak saran maupun angket.

\section{Transparansi Pengelolaan APB Nagari}

a. Terdapat pengumuman kebijakan anggaran 
Pemerintah Nagari Balimbing sudah menyediakan informasi kebijakan publik melalui baliho atau spanduk tentang pembangunan fisik dan alokasi dana nagari yang dipajang di dinding depan kantor wali nagari Balimbing (Jeli Fitrina, Wawancara, 18 Juli 2017).

b. Tersedia dokumen anggaran yang mudah diakses.

Pemerintah nagari Balimbing belum menyediakan informasi laporan pertanggungjawaban realisasi pelaksanaan APB Nagari yang mudah diakses oleh masyarakat nagari, baik melalui media internet dan media cetak. Media internet merupakan media yang paling mudah diakses oleh masyarakat. Kapanpun dan dimanapun masyarakat bisa mengaksesnya. Namun, yang menjadi kendala bagi pemerintah nagari Balimbing adalah jaringan internet.

c. Tersedianya laporan tepat waktu

Pemerintah nagari Balimbing sudah membuat laporan pertanggungjawaban realisasi pelaksanaan anggaran dibuat setiap akhir bulan dilaporkan oleh bendahara nagari kepada wali nagari, setiap 3 bulan pembukuan tersebut ditutup dengan persetujuan wali nagari. Laporan tersebut dibuat berdasarkan sifat bulanan, triwulan, semesteran, dan tahunan (Jeli Fitrina, Wawancara, 18 Juli 2017).

d. Terakomodasinya suara/usulan rakyat

Kegiatan-kegiatan pembangunan yang dilaksanakan oleh nagari Balimbing merupakan usulan dari masyarakat nagari Balimbing. Pada tiap-tiap jorong di nagari Balimbing diadakan pra musyawarah untuk membicarakan kegiatan apa sajakah yang akan dilaksanakan dan berapa dana yang dibutuhkan. Dari pra musyawarah tersebut, maka setiap usulan dari masyarakat jorong dirumuskan atau disusun oleh pemerintah nagari menjadi rancangan peraturan nagari tentang APB Nagari (Jeli Fitrina, Wawancara, 18 Juli 2017).

e. Terdapat sistem pemberi informasi kepada publik 
Pemerintah nagari Balimbing belum menyediakan website resmi untuk mempublikasikan ILPPN kepada masyarakat, karena terkendala jaringan (Yasripen, Wawancara, 4 Juli 2017).

Berdasarkan wawancara dengan Bapak Yasripen, S.Ag, pemerintah nagari Balimbing belum menyediakan sistem pemberi informasi kepada publik seperti website resmi Nagari Balimbing karena terkendala jaringan.

\section{PENUTUP}

Berdasarkan hasil penelitian Akuntabilitas dan Transparansi Pengelolaan Anggaran Pendapatan dan Belanja Nagari (APB Nagari) di Nagari Balimbing Kecamatan Rambatan Kabupaten Tanah Datar dapat disimpulkan dari hasil pembahasan bahwa:

1. Akuntabilitas Pengelolaan APB Nagari

Akuntabilitas pengelolaan APB Nagari yang dikelola oleh pemerintah nagari Balimbing sudah diterapkan dengan baik. Pemerintah nagari sudah menerapkan prinsip akuntabilitas, namun masih ada beberapa indikator dari kriteria akuntabel menurut Sulistoni dalam Ony dan Irvan yang belum diterapkan. Pemerintah nagari Balimbing sudah membuat dan menyusun laporan pertanggungjawaban realisasi pelaksanaan anggaran berdasarkan peraturan perundang-undangan yang berlaku. Dalam pelaporan, pemerintah nagari Balimbing telah menyampaikan laporan pertanggungjawaban realisasi pelaksanaan anggaran kepada bupati Tanah Datar. Dari segi penyampaian laporan kepada masyarakat, pemerintah nagari telah menyampaikan laporan pertanggungjawaban realisasi pelaksanaan anggaran kepada masyarakat melalui rapat. Dalam penyusunan anggaran pada tahap perencanaan, masyarakat diikutsertakan dalam pra musyawarah yang diadakan di setiap jorong-jorong yang ada di nagari Balimbing. Pada pra musyawarah tersebut, masyarakat mengemukakan ide-idenya dalam menyusun kegiatan-kegiatan apa yang akan dilaksanakan di nagari Balimbing. Dalam proses pelaksanaan, masyarakat diikutsertakan dalam tim 
pelaksanaan kegiatan (TPK). Masyarakat yang diikutsertakan menjadi TPK merupakan masyarakat yang telah disetujui dalam musyawarah pembangunan nagari.

Indikator akuntabilitas yang belum diterapkan pada pengelolaan APB Nagari yaitu belum tersedianya sarana berupa kotak saran atau pengisian angket untuk penilaian kinerja pemerintah nagari. Dengan adanya sarana penilaian kinerja pemerintah nagari oleh masyarakat, masyarakat bisa menyampaikan aspirasinya melalui media tersebut, demi meningkatkan kualitas kinerja pemerintah nagari.

2. Transparansi Pengelolaan APB Nagari

Transparansi dalam pengelolaan APB Nagari sudah diterapkan di nagari Balimbing, namun ada beberapa indikator dari kriteria transparansi yang dikemukakan oleh Sopanah dan Mardiasmo dalam Ony dan Irvan yang belum diterapkan. Indikator transparansi yang sudah diterapkan yaitu: Pengumuman kebijakan anggaran telah dipublikasikan melalui Baliho atau spanduk. Laporan telah disajikan tepat waktu oleh pemerintah nagari, yaitu paling lambat satu bulan setelah masa anggaran berakhir. Pemerintah nagari sudah menciptakan terakomodasinya suara atau usulan masyarakat. Penyusunan APB Nagari telah disusun berdasarkan usulan dari masyarakat nagari Balimbing. Indikator transparansi yang belum diterapkan yaitu: Laporan realisasi APB Nagari belum dipublikasikan melalui media yang mudah diakses seperti media cetak, internet, radio komunitas dan lainnya. Ada kendala yang dihadapi pemerintah nagari Balimbing dalam mempublikasikan laporan pertanggungjawaban realisasi pelaksanaan APB Nagari yang mudah diakses yaitu jaringan, menurut Bapak Yasripen, untuk kedepannya akan diadakan pembangunan tower dan menyediakan website, agar transparansi pengelolaan keuangan desa dapat diakses oleh masyarakat melalui media internet. 


\section{DAFTAR PUSTAKA}

Afrizal. (2014). Metodelogi Penelitian Kualitatif. Jakarta: PT. Raja Grafindo Persada.

Ahmadi, R. (2014). Metodologi Penelitian Kualitatif. Yogyakarta: AR-Ruzz Media.

Badan Pengawasan Keuangan dan Pembangunan. (2015). Petunjuk Pelaksanaan Bimbingan dan Konsultasi Pengelolaan Keuangan Desa. Deputi Bidang Pengawasan Penyelenggaraan Keuangan Daerah.

Bastian, I. (2015). Akuntansi Untuk Kecamatan dan Desa. Jakarta: PT. Gelora Aksara Pratama.

Bupati Tanah Datar. (2016). Peraturan Bupati Tanah Datar Nomor 11 Tahun 2016 Tentang Pedoman Penyusunan Anggaran Pendapatan Belanja Nagari dan Standar Biaya Umum Pemerintah Nagari.

Faridah. (2015). Transparansi Dan Akuntabilitas Pemerintah Desa Dalam Pengelolaan Anggaran Pendapatan Dan Belanja Desa (APBDes), Jurnal Ilmu \& Riset Akuntansi Vol. 4 No. 5, Sekolah Tinggi Ilmu Ekonomi Indonesia (STIESIA) Surabaya.

Halim, A. (2007). Akuntansi dan Pengendalian Pengelolaan Keuangan Daerah, Yogyakarta: UPP STIM YKPN Yogyakarta.

Halim, A. (2013). Teori, Konsep, dan Aplikasi Akuntansi Sektor Publik dari Anggaran Hingga Laporan Keuangan, Dari Pemerintah Hingga Tempat Ibadah. Jakarta: Salemba Empat.

Hamzah, A. (2015). Tata Kelola Pemerintahan Desa Menuju Desa Mandiri, Sejahtera, dan Partisipatoris. Penerbit Pustaka Jawa Timur.

Hanifah, S. I. (2015). Akuntabilitas Dan Transparansi Pertanggungjawaban Anggaran Pendapatan BelanjaDesa (APBDes). Jurnal Ilmu \& Riset Akuntansi Vol. 4 No. 8 (2015). STIESIA Surabaya.

Ikatan Akuntansi Indonesia. (2015). Kompartemen ASP; Pedoman Asistensi Akuntansi Keuangan Desa.

Kementerian Keuangan Republik Indonesia. (2016). Kebijakan Pengalokasian dan Penyaluran Dana Desa Tahun 2017. http://www.djpk.depkeu.go.id/wpcontent/uploads/2016/11/Paparan-Kemenkeu.pdf 
Kumalasari, D. (2016). Transparansi dan Akuntabilitas Pemerintah Desa dalam Pengelolaan Alokasi Dana Desa. Jurnal Ilmu dan Riset Akuntansi: Vol. 5 No. 11, November 2016. STIESIA Surabaya.

Lestari, A. K. D. (2014). Membedah Akuntabilitas Praktik Pengelolaan Keuangan Desa Pakraman Kubutambahan, Kecamatan Kubutambahan, Kabupaten Buleleng, Provinsi Bali. E-Journal S1 AkUniversitas Pendidikan Ganesha. Vol. 2 No. 1 Tahun 2014.

Mahmudi. (2007). Manajemen Kinerja Sektor Publik Edisi Pertama Cetakan Kedua. Yogyakarta: UPP AMP YKPN.

Mahmudi. (2011). Akuntansi Sektor Publik. Yogyakarta: UII Pres.

Mahmudi. (2015). Manajemen Kinerja Sektor Publik Edisi Ketiga Cetakan Pertama. Yogyakarta: UPP STIM YKPN.

Mardiasmo. (2009). Akuntansi Sektor Publik. Yogyakarta: Andi Offset.

Mendagri. (2014). Peraturan Menteri Dalam Negeri Nomor 113 Tahun 2014 Tentang Pengelolaan Keuangan Desa.

Mendagri. (2014). Peraturan Menteri Dalam Negeri Nomor 114 Tahun 2014 Tentang Pedoman Pembangunan Desa.

Noor, J. (2011). Metodelogi Penelitian: Skripsi, Tesis, disertai, dan Karya Ilmiah. Jakarta: Kencana Prenada Media Grup.

Presiden Republik Indonesia. (2010). Peraturan Pemerintah Nomor 71 Tahun 2010 Tentang Standar Akuntansi Pemerintah.

Presiden Republik Indonesia. (2014). Peraturan Pemerintah Nomor 43 Tahun 2014 Tentang Peraturan Pelaksanaan Undang-Undang Nomor 6 Tahun 2014 tentang Desa.

Republik Indonesia. (2014). Undang-undang nomor 6 tahun 2014 Tentang Desa.

Sarosa, S. (2012). Penelitian Kualitatif: Dasar-dasar. Jakarta: Indeks.

Sugiyono. (2015). Metode Penelitian Manajemen. Bandung: Alfabeta.

Sujarweni, W. (2015). Akuntansi Desa-Panduan Tata Kelola Keuangan Desa, Jakarta: Pustaka Baru Press.

Sumpeno, W. (2011). Perencanaan Desa Terpadu. Banda Aceh-Indonesia-Read. 
Widilestariningtyas, O dan Irvan, P. (2012). Implementasi Transparansi dan Akuntabilitas Dalam Upaya Peningkatan Kualitas Laporan Keuangan Pemerintah Daerah. Jurnal Universitas Komputer Indonesia.

Yuliansyah dan Rusmianto. (2016). Akuntansi Desa. Jakarta: Salemba Empat. 